\title{
Ekstrak Metanol Daun Kelor Mempengaruhi Ekspresi p53 Mukosa Kolon Tikus yang Diinduksi DMBA
}

\section{Methanol Extract Moringa oleifera Leaves Affects p53 Expression in Rattus novergicus Colon Mucosa Induced by DMBA}

\author{
Fitria Nurindo $R^{1}$, M Rasjad Indra ${ }^{2}$, Diana Lyrawati ${ }^{3}$ \\ ${ }^{1}$ Program Studi Pendidikan Dokter Fakultas Kedokteran Universitas Brawijaya Malang \\ ${ }^{2}$ Laboratorium IImu Faal Fakultas Kedokteran Universitas Brawijaya Malang \\ ${ }^{3}$ Laboratorium Farmasi Fakultas Kedokteran Universitas Brawijaya Malang
}

\begin{abstract}
ABSTRAK
Protein p53 berperan pada jalur respon stres yang mencegah pertumbuhan dan survival sel-sel yang memiliki potensi keganasan dan banyak diekspresikan pada sel yang mengalami mutasi dan stres genotoksik. Penelitian ini bertujuan mengetahui pengaruh ekstrak metanol daun Moringa oleifera terhadap jumlah epitel yang mengekspresikan p53 pada mukosa kolon Rattus novergicus strain wistar jantan yang diinduksi DMBA. Penelitian ini merupakan penelitian eksperimental dengan rancangan post test control group design yang menggunakan 20 ekor tikus wistar jantan yang dibagi secara acak menjadi lima kelompok. Kelompok I diberi diet normal tanpa DMBA dan ekstrak metanol daun Moringa oleifera selama 105 hari. Kelompok II diberi diet normal dan DMBA 10 mg/kgBB/hari per oral selama 45 hari, dilanjutkan dengan diet normal saja selama 60 hari. Kelompok III-V diberi diet normal dan DMBA $10 \mathrm{mg} / \mathrm{kgBB} /$ hari per oral selama 45 hari, dilanjutkan dengan diet normal dan ekstrak metanol daun Moringa oleifera dalam berbagai dosis (20, 40, dan 80 $\mathrm{mg} / \mathrm{kgBB} /$ hari) per oral selama 60 hari. Jumlah epitel yang mengekspresikan p53 pada mukosa kolon tikus dihitung menggunakan metode imunohistokimia. Analisis data menggunakan metode One Way ANOVA diikuti dengan uji post hoc Tukey menunjukkan bahwa ekstrak metanol daun Moringa oleifera memberikan pengaruh yang signifikan terhadap jumlah epitel yang mengekspresikan p53 ( $p=0,042$ ) (dari 12 sel pada kelompok II menjadi 5 sel pada kelompok IV per 60.000 sel). Kesimpulan penelitian ini adalah ekstrak metanol daun Moringa oleifera dapat menurunkan jumlah epitel yang mengekspresikan p53 pada mukosa kolon tikus wistar jantan yang diinduksi DMBA.
\end{abstract}

Kata Kunci: Daun Moringa oleifera, DMBA, ekstrak metanol, p53

\begin{abstract}
Protein $p 53$ roled in the stress response which prevent the growth and survival of the cell with malignancy potential, expressed in the mutated cell and genotoxic stress. The purpose of the research is to determine the methanol extract of Moringa oleifera leaf effect to the number of epithel expressed 553 on male Rattus novergicus strain colon mucose induced by DMBA. This is an experimental research using post test control group design with sample of 20 male wistar rat divided randomly into 5 groups. First group given normal diet without DMBA and methanol extract of Moringa oleifera leaffor 105 days. Second group given normal diet without DMBA $10 \mathrm{mg} / \mathrm{kg}$ body weight/day orally for 45 days, continued with normal diet only for 60 days. Group 3-5 given normal diet and DMBA $10 \mathrm{mg} / \mathrm{kg}$ body weight/day orally for 45 days, continued with normal diet and methanol extract of Moringa oleifera leaf in voarious doses (20,40, and $80 \mathrm{mg} / \mathrm{kg}$ body weight/day) orally for 60 days. The number of epithel expressed $p 53$ on rat colon mucose counted with immunohistochemistry method. Data analysis using one way ANOVA followed by post hoc Tukey test showed that methanol extract of Moringa oleifera give a significant effect to the number of epithel expressed $p 53(p=0,042)$ (from 12 cell in group II to 5 cell in group IV per 60.000 cell). From the research it can be concluded that methanol extract of Moringa oleifera decrease the number of epithel expressed 553 on male wistar rat colon mucose induced by DMBA.
\end{abstract}

Keywords: DMBA, methanol extract, Moringa oleifera leaf, p53

Jurnal Kedokteran Brawijaya, Vol. 27, No. 4, Agustus 2013; Korespondensi: Diana Lyrawati. Laboratorium Farmasi Fakultas Kedokteran Universitas Brawijaya Malang, Jl.Veteran Malang Tel. (0341) 560491Email:eldi_7_98@yahoo.com 


\section{PENDAHULUAN}

Satu dari delapan kematian di dunia disebabkan oleh kanker. Kanker menyebabkan kematian lebih banyak daripada gabungan kematian karena AIDS, tuberkulosis, dan malaria (1). Kanker kolorektal merupakan kanker ke-3 terbanyak pada laki-laki dan ke-2 terbanyak pada perempuan di dunia dan merupakan penyebab kematian karena kanker terbanyak ke-4. Hampir 60\% kasus terjadi di negara berkembang (2). Pada kebanyakan kasus kanker kolorektal, mutasi DNA yang menginisiasi kanker didapatkan selama kehidupan seseorang, bukan diwariskan (3). Salah satu faktor lingkungan yang telah diketahui memiliki peran dalam terjadinya kanker adalah Polycyclic Aromatic Hydrocarbons (PAH) (4).

Berdasarkan estimasi International Agency for Research on Cancer (IARC), pada tahun 2030 akan terjadi peningkatan global kasus kanker baru dan peningkatan angka kematian karena kanker disebabkan oleh pertumbuhan dan penuaan populasi sementara kematian anak dan kematian karena infeksi di negara berkembang berkurang (3). Oleh karena itu, dibutuhkan upaya pencegahan terhadap kanker untuk menghindari kecacatan serta kematian pada kasus-kasus baru.

Pengobatan kanker sampai saat ini telah dilakukan dengan berbagai cara dengan target terapi yang berbeda-beda, salah satunya dengan cara memacu apoptosis dan mengurangi tingkat cell survival untuk mengontrol jumlah dan proliferasi sel yang melibatkan protein p53 (5). Protein p53 berperan pada jalur respon stress yang mencegah pertumbuhan dan survival dari sel-sel yang memiliki potensi keganasan. Banyak tipe stress mengaktivasi p53, termasuk kerusakan DNA, erosi telomer, aktivasi onkogen, hipoksia, stress metabolik, dan berkurangnya sinyal pertumbuhan normal dan survival. Sehingga dapat dikatakan p53 berperan dalam mencegah pertumbuhan sel tumor pada beberapa tahapan proses keganasan (6).

Indonesia sebagai negara tropis mempunyai keragaman flora yang berpotensi untuk dikembangkan dalam dunia pengobatan. Daun kelor (Moringa oleifera) memiliki banyak manfaat diantaranya untuk kurang energi protein. Tanaman ini tersebar di daerah tropis, termasuk Indonesia (7). Moringa oleifera telah diketahui memiliki efek supresi tumor karena kandungan antioksidannya yang tinggi (8). Efek antioksidan dalam Moringa oleifera salah satunya diperankan oleh flavonoid yang terkandung di dalamnya. Beberapa flavonoid yang telah diketahui terkandung dalam Moringa oleifera adalah kaempferol, quercetin, rhamnetin, quercetagetin, dan proanthocyanidin (9). Dengan demikian, daun Moringa oleifera diharapkan dapat menjadi obat herbal untuk pencegahan dan pengobatan kanker. Pada penelitian ini diteliti efek ekstrak Moringa terhadap p53 sebagai salah satu petanda apoptosis pada sel kolon binatang coba yang dinduksi zat karsinogen 7,12 dimetilbenzen-antrasena (DMBA).

\section{METODE}

\section{Desain Penelitian}

Penelitian ini merupakan penelitian eksperimental dengan post test control group design dengan subjek dibagi menjadi 5 kelompok (I sampai dengan V) secara acak. Tiap kelompok terdiri dari 6 tikus. Kelompok I adalah tikus yang diberi diet normal tanpa induksi DMBA dan ekstrak metanol daun Moringa oleifera (kontrol negatif), kelompok II tikus diberi diet normal dan induksi DMBA (kontrol positif), sedangkan kelompok III sampai dengan $\mathrm{V}$ (Perlakuan I-III) diinduksi DMBA dan ekstrak metanol daun kelor (Moringa oleifera) dalam berbagai dosis.

\section{Pemeliharaan}

Dalam masa ini, kelima kelompok tikus mendapat perlakuan yang berbeda. Tikus wistar yang ada dibagi menjadi 5 kelompok (I-V). Kelima kelompok tikus mendapat perlakuan yang berbeda. Kelompok I diberi diet normal tanpa DMBA dan ekstrak metanol daun Moringa oleifera selama 105 hari. Kelompok II diberi diet normal dan DMBA $10 \mathrm{mg} / \mathrm{kgBB} /$ hari per oral selama 45 hari, dilanjutkan dengan diet normal saja selama 60 hari. Kelompok III-V diberi diet normal dan DMBA 10 $\mathrm{mg} / \mathrm{kgBB} /$ hari per oral selama 45 hari, dilanjutkan dengan diet normal dan ekstrak metanol daun Moringa oleifera dalam berbagai dosis $(20,40$, dan $80 \mathrm{mg} / \mathrm{kgBB} /$ hari) per oral selama 60 hari. Semua ekstrak daun kelor di atas diberikan selama 60 hari, sedangkan pakan normal selama 105 hari (10). Semua perlakuan di atas telah disetujui oleh Komisi Etik Penelitian Kesehatan Fakultas Kedokteran Universitas Brawijaya dengan nomor surat kelaikan etik No.265/EC/KEPK-SI/09/2012

\section{Proses Ekstraksi Daun Kelor}

Proses ekstraksi menggunakan 42 gram tepung daun kelor (Moringa oleifera) yang direndam dengan metanol sampai volume $900 \mathrm{ml}$, dikocok 30 menit lalu di biarkan semalam. Lapisan atas campuran metanol diambil dengan zat aktif. Metanol dialirkan sampai berhenti menetes pada labu penampung (1,5 sampai 2 jam untuk 1 labu). Hasil yang diperoleh kira-kira sepertiga dari bahan alam kering. Hasil ekstraksi kemudian disimpan dalam freezer (11).

\section{Pemeriksaan p53 Menggunakan Metode Imunohistokimia}

Jaringan kolon dipotong setebal 2-3 mm, kemudian dimasukkan ke kaset sesuai dengan kode gross. Setelah itu dilakukan fiksasi dengan memasukkan jaringan ke dalam formalin 10\%. Dan diproses menggunakan mesin Tissue Tex Processor. Jaringan diangkat dari mesin Tissue Tex Processor dan diblok dengan paraffin sesuai dengan kode jaringan, lalu dipotong dengan mesin microtome dengan ketebalan 3-5 $\mu \mathrm{m}$. Setelah jaringan dipotong dengan mesin microtome, dimasukkan ke dalam oven dengan suhu $70^{\circ} \mathrm{C}$ selama 15 menit, kemudian dimasukkan ke dalam xylol (Merck) sebanyak dua kali, dengan masingmasing tahap selama 15 menit dan suhu xylol $70^{\circ} \mathrm{C}$ dilanjutkan dengan perendaman pada alkohol $96 \%$ sebanyak empat kali dengan masing-masing tahap selama 3 menit dan dicuci dengan air mengalir selama 10 menit.

Setelah itu dilakukan pemberian antibodi primer p53 (Santa Cruz) pada suhu $37^{\circ} \mathrm{C}$ selama 60 menit, lalu dibilas dengan PBS 3 kali masing-masing selama 5 menit dan diseka dengan tisu. Pengecetan dengan antibodi sekunder (Santa Cruz) dilakukan selama 60 menit lalu dibilas lagi dengan PBS 2 kali selama masing-masing 5 menit dengan tisu. SA-HRP (IHCworld) 60 menit, dibilas dengan PBS 2 kali masing-masing dan diseka dengan tisu. Warna dimunculkan dengan pemberian DAB (IHCworld) selama 20 menit. Setelah dicuci dengan aquadest $2 x$ masingmasing 5 menit dan diseka dengan tisu dilakukan counterstaining dengan Mayer hematoksilin 10 detik. Setelah dicuci dengan air kran dan dikeringkan dengan 
tisu, dilakukan mounting dengan Entelan dan diobservasi menggunakan mikroskop cahaya (Olympus) perbesaran 400x untuk melihat ekspresi protein p53.

\section{Analisis Data}

Hasil penghitungan jumlah ekspresi p53 pada epitel mukosa kolon tikus dianalisis dengan menggunakan program SPSS 16 untuk Windows XP. Metode analisis menggunakan uji normalitas data (Kolmogorov-Smirnov dan Shapiro-Wilk), uji homogenitas (Levene test), uji Oneway ANOVA, dan uji Post hoc Tukey HSD.

\section{HASIL}

Pada penelitian ini dibuat binatang model untuk menggambarkan efek ekstrak daun Moringa oleifera pad pencegahan progresi karsinogenesis kolon yang diinduksi dengan pemberian DMBA. Pada hari ke-45 induksi DMBA dilakukan pembedahan pada salah satu hewan coba kelompok kontrol positif dan dilakukan pemeriksaan histologi terhadap jaringan kolon untuk melihat progresifitas karsinogenesis. Gambaran histologi yang didapatkan dari pemeriksaan tersebut menunjukkan adanya hiperplasia pada mukosa kolon (Gambar 1A). Pemeriksaan histologi untuk mendeteksi ekspresi p53 jaringan kolon juga dilakukan setelah DMBA dihentikan pada hari ke-45 dan dilanjutkan dengan diet normal dengan atau tanpa suplementasi ekstrak Moringa selama 60 hari. Hasil pemeriksaan histologi, secara morfologi tidak terlihat perbedaan baik pada kontrol negatif diet normal tanpa DMBA; kontrol positif yang diinduksi DMBA tanpa ekstrak Moringa; dan kelompok perlakukan DMBA yang dilanjutkan dengan pemberian Moringa (Gambar 1). Dari pemeriksaan imunohistologi p53, terdapat perbedaan ekspresi p53 pada kelompok negatif, kelompok kontrol positif dan perlakuan Moringa (Gambar 1).

Pemberian karsinogen DMBA (kontrol positif) menunjukkan eskpresi p53 yang lebih tinggi (0,02\%) secara signifikan $(p=0,25)$ dibandingkan kondisi normal $(0,005 \%)$. Efek perlakuan pada dosis $40 \mathrm{mg}$ dan 80 $\mathrm{mg} / \mathrm{kgBB} /$ hari memberikan ekspresi p53 yang lebih rendah $(0,005 \%)$ dibandingkan kontrol positif hingga sama dengan kondisi normal (Tabel1).

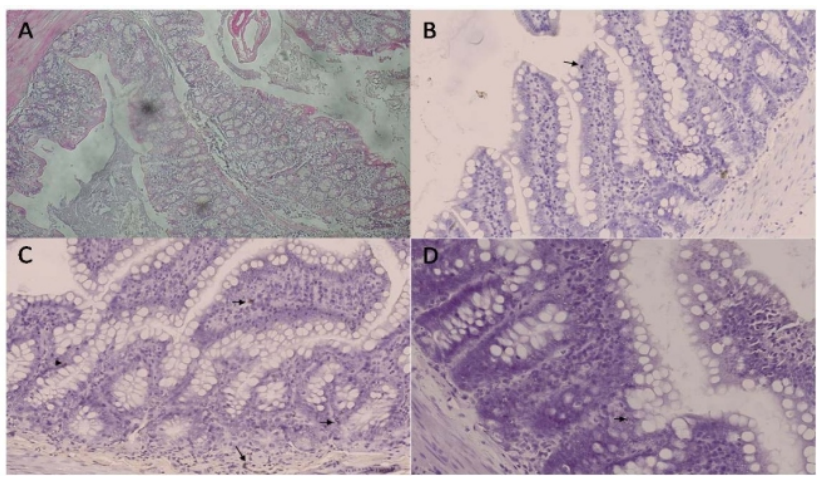

Gambar 1. Histologi jaringan kolon

Keterangan: (A) Kontrol Positif pada hari ke-45 induksi DMBA, (B) Kontrol Negatif diet normal tanpa DMBA, (C) Kontrol positif DMBA setelah 60 hari dihentikan (post-withdrawal DMBA), (D) Kelompok perlakuan postwithdrawal DMBA yang mendapat ekstrak Moringa $80 \mathrm{mg} / \mathrm{kgBB} / \mathrm{hari}$ selama 60 hari. Tanda panah menunjukkan sel yang mengekspresikn p53 (warna coklat pada inti sel). Perbesaran 400x.
Tabel 1. Rata-rata jumlah epitel yang mengekspresikan p53 dalam \%

\begin{tabular}{lccccc}
\hline Kelompok & N $\begin{array}{c}\text { Jumlah sel dengan } \\
\text { ekspresi p53 per } \\
\mathbf{6 0 . 0 0 0} \text { sel }\end{array}$ & Rerata (\%) & $\begin{array}{c}\text { Standar } \\
\text { Deviasi }\end{array}$ & $\begin{array}{c}\text { p } \\
\text { (ANOVA) }\end{array}$ \\
\hline 1 Kontrol Negatif & 4 & 3 & $0,0050^{\text {a }}$ & 0,0064 & \\
2 Kontrol Positif & 4 & 12 & $0,0200^{\text {b }}$ & 0,0054 & \\
3 Moringa 20 mg & 4 & 5 & $0,0083^{\text {ab }}$ & 0,0084 & 0,025 \\
4 Moringa 40 mg & 4 & 3 & $0,0050^{\text {a }}$ & 0,0064 & \\
5 Moringa 80 mg & 4 & 3 & $0,0050^{\text {a }}$ & 0,0064 & \\
\hline
\end{tabular}

Keterangan: notasi $(a, b)$ yang berbeda menunjukkan perbedaan yang signifikan $(p<0,05)$ setelah uji Tukey

Dari Tabel 2 didapatkan adanya perbedaan signifikan pada jumlah epitel yang mengekspresikan p53 pada mukosa kolon kelompok Kontrol Negatif dengan kelompok Kontrol Positif; kelompok Kontrol Positif dengan kelompok Perlakuan II; dan kelompok Kontrol Positif dengan kelompok Perlakuan III ( $p=0,042$ uji Tukey).

\section{DISKUSI}

Pada penelitian ini, walaupun telah terlihat hiperplasia pada 45 hari induksi DMBA (post-induction) pada jaringan kolon, setelah 60 hari penghentian pemberian DMBA (post-withdrawal) diperoleh data yang menunjukkan bahwa tidak terlihat perbedaan morfologi sel mukosa kolon baik pada kelompok kontrol negatif, kontrol positif maupun kelompok perlakuan suplementasi ekstrak Moringa. Hal ini mungkin disebabkan oleh kemampuan regenerasi serta repair kerusakan DNA pada sel kolon yang cepat dapat mengimbangi efek DMBA sehingga setelah 60 hari postwithdrawal DMBA, sel-sel mukosa kolon sudah nampak normal seperti kelompok kontrol negatif. Penelitian lebih lanjut dengan menguji kecepatan proliferasi dan regenerasi kolon serta uji kerusakan DNA dan repairnya pada masa-masa setelah penghentian induksi DMBA diperlukan untuk memvalidasi kemungkinan tersebut.

Walaupun observasi morfologi sel tidak menunjukkan perbedaan pada semua kelompok, namun jika dilihat dari ekspresi p53 data penelitian menunjukkan secara statistik terdapat perbedaan bermakna antara kelompok kontrol negatif, positif dan Moringa oleifera pada dosis 40 dan $80 \mathrm{mg} / \mathrm{kgBB} /$ hari (ANOVA $\mathrm{p}=0,025$ ). Moringa oleifera diketahui memiliki efek kemopreventif dan inhibisi produksi radikal bebas seperti reactive oxygen species (ROS) melalui modulasi enzim detoksifikasi seperti sitokrom b5, sitokrom P450, katalase, reduktase, Stransferase, dan glutathione-peroxidase (12). Paparan DMBA menginduksi perubahan patologi klinik melalui toksisitas yang terjadi pada kulit, ovarium, mukosa buccal, kelenjar mammae, hepar, ginjal, dan kolon (13). Pada penelitian ini jumlah epitel yang mengekspresikan p53 masih terlihat lebih tinggi pada jaringan kolon tikus yang pernah diinduksi DMBA (60 hari postwithdrawal) dibanding pada kelompok kontrol negatif yang tidak pernah mendapat induksi DMBA maupun pada kelompok postwithdrawal DMBA yang kemudian mendapat suplementasi ekstrak Moringa. Jumlah epitel yang mengekspresikan p53 setelah pemberian ekstrak metanol daun Moringa oleifera lebih sedikit daripada kelompok 
kontrol positif DMBA yang tidak mendapat Moringa. Pemberian ekstrak metanol daun Moringa oleifera yang mungkin mengandung antioksidan (flavonoid, alkaloid, niazimicin, glucomoringin, vitamin $\mathrm{C}$ dan E) diperkirakan menghambat pembentukan radikal bebas lebih lanjut, juga menghambat terbentuknya metabolit DMBA-DE yang dapat berikatan dengan DNA yang mengakibatkan kerusakan DNA sehingga ekspresi dan aktivasi p53 menurun jumlahnya (14). Flavonoid mempunyai kecenderungan mengikat atom, atau sebagai "scavenging" bagi radikal bebas sehingga tidak terbentuk ROS berlebihan (14). Antioksidan merupakan senyawa pelindung sel melawan efek merusak dari Reactive Oxygen Species (ROS). Ketidakseimbangan antara antioksidan dengan ROS menimbulkan oxidative stress dan memicu kerusakan selular. Oxidative stress berhubungan dengan kanker, penuaan, atherosklerosis, dan inflamasi (15).

Senyawa bioaktif flavonol lain yang ditemukan pada daun Moringa oleifera adalah quercetin dan kaempferol dengan bentuk 3'-O-glikosida $(16,17)$. Kadar quercetin mencapai $100 \mathrm{mg} / 100 \mathrm{~g}$ daun kelor (18). Quercetin merupakan antioksidan kuat, dengan kekuatan 4-5 kali lebih tinggi dibandingkan vitamin C dan vitamin E (19). Quercetin juga diketahui memiliki potensi anti kanker melalui induksi apoptosis (20). Kaempferol menunjukkan penghambatan yang poten terhadap aktifitas generasi ROS (21). Kaempferol juga merupakan antioksidan kuat dan memiliki potensi anti kanker, terutama dengan menghambat proliferasi dan meningkatkan apoptosis pada sel kanker kolon (22). Selain itu Niazimicin, salah satu

\section{DAFTAR PUSTAKA}

1. World Health Organization. Are the Number of Cancer Cases Increasing or Decreasing in the World? (Online) 1998. http://www.who.int/features/qa/15/en/ [diakses tanggal 1 Desember 2011].

2. GLOBOCAN 2008. Fact Stats World. (Online) 2010. http://globocan.iarc.fr/factsheets/populations/facts heet.asp?uno $=900$ [diakses tanggal 9 Desember 2011].

3. American Cancer Society. Colorectal Cancer. (Online) 2011. http://www.cancer.org/acs/groups /cid/documents/webcontent/003096-pdf.pdf. [diakses 23 Desember 2011].

4. Al-Attar AM. The Influence of Dietary Grapeseed Oil on DMBA-Induced Liver Enzymes Disturbance in the Frog, Rana ridibunda. Pakistan Journal of Nutrition. 2004; 3(5): 304-309.

5. Kaufmann Y, Luo S, Johnson A, Babb K, and Klimberg VS. Timing of Oral Glutamine on DMBA-induced Tumorigenesis. Journal of Surgery Research. 2003; 111(1): 158-165

6. Bai $L$ and Zhu W. 2006. p53: Structure, Function and Therapeutic Applications. Journal of Cancer Molecules. 2006; 2(4): 141-153.

7. Morimitsu Y, Hayashi K, Nakagawa Y, Horio F, Uchida K, and Osawa T. 2000. Antiplatelet and Anticancer Isothiocyanates in Japanese Domestic Horseradish, Wasabi. BioFactors. 2000; 13(1-4): 271-276. alkaloid pada Moringa oleifera juga diketahui memiliki potensi antitumor pada karsinogenesis kanker kulit pada mencit yang diinduksi DMBA (23). Daun Moringa oleifera sebagai substansi yang mencegah sekaligus menghambat dan mengatasi perkembangan terjadinya karsinogenesis kolon lebih lanjut, juga ditandai dengan adanya penurunan Cyclin D1 (24).

Dosis pada penelitian ini yaitu $20-80 \mathrm{mg} / \mathrm{kgBB} / \mathrm{hari}$ yang menunjukkan efek kemopreventif lebih rendah dari dosis penelitian lain yaitu penghambatan proliferasi tumor dan inhibisi ROS pada dosis $200 \mathrm{mg} / \mathrm{kgBB} /$ hari dan 400 $\mathrm{mg} / \mathrm{kgBB} / \mathrm{hari}$ (25) Efek yang secara statistik bermakna, tidak berarti secara klinis juga bermakna, mengingat pada penelitian ini jumlah sel yang menunjukkan ekspresi p53 relatif sedikit, yaitu 12 sel per 60.000 sel pada kelompok DMBA yang tidak mendapat ekstrak dan $5 ; 3$ dan 3 sel per 60.000 sel pada kelompok DMBA yang mendapat ekstrak Moringa oleifera. Masih diperlukan penelitian lebih lanjut terkait potensi daun Moringa oleifera untuk menjadi salah satu kandidat agen prevensi dan terapi kanker dalam aplikasi klinis. Demikian juga dari segi keamanan klinis, walaupun telah dilaporkan pada mencit tidak terdapat efek samping pada pemberian ekstrak daun Moringa oleifera yang diberi dosis $400 \mathrm{mg} / \mathrm{kgBB} /$ hari selama 21 hari (26).

Ekstrak metanol daun Moringa oleifera dapat menurunkan jumlah epitel yang mengekspresikan p53 pada mukosa kolon tikus Wistar yang diinduksi DMBA, seperti pada kelompok normal tanpa induksi DMBA. Dosis yang menunjukkan respon tersebut pada penelitian ini adalah 40 dan $80 \mathrm{mg} / \mathrm{kgBB} /$ hari.

8. Murakami A, Kitazono Y, Jiwajinda S, Koshimizu K, Ohigashi $\mathrm{H}$, and Naizimin. A Thiocarbamate from the Leaves of $M$. oleifera, Holds a Strict Structural Requirement for Inhibition of Tumor-promoterinduced Epstein-Barr Virus Activation. Planta Medica. 1998; 64(4): 319-323.

9. Saleem R. Studies in the Chemical Constituents of Moringa oleifera Lam., and Preparation of Potential Biologically Significant Derivatives of 8hydroxyquinoline. [Repository]. University of Karachi, Karachi. 1995.

10. Indra MR, Hernowati TE, dan Satuman. Pengaruh Ekstrak Daun Kelor (Moringa Oleifera) terhadap Efek Karsinogenik Polutan 7,12 Dimethyl Benz(A)Nthracene (Dmba) Pada Tikus Wistar Melalui Penghambatan Aktifitas Telomerase dan Induksi Apoptosis. Malang: Laboratorium IImu Faal Fakultas Kedokteran Universitas Brawijaya; 2011.

11. Sultana B, Anwar F, and Ashraf M. Effect of Extraction Solvent/Technique on the Antioxidant Activity of Selected Medicinal Plant Extracts. Molecules. 2009; 14(6): 2167-2180.

12. Bharali R, Tabassum J, and Azad MR. Chemomodulatory effect of Moringa oleifera Lam on Hepatic Carcinogen Metabolizing Enzymes, Antioxidant Parameters and Skin Papillomagenesis in Mice. Asian Pacific Journal of Cancer Prevention. 2003; 4(2): 131-139.

13. Saha D and Milan H. An Ontological Design: Two Stage 
Mouse Skin Carcinogenesis Induced by DMBA and Promoted by Croton Oil. Asian Journal of Research in Pharmaceutical Sciences. 2012; 2(1): 1-3.

14. Nakagawa K, Kawagoe $M$, Yoshimura $M$, et al. Differential Effects of Flavonoid Quercetin on Oxidative Damages Induced by Hydrophilic and Lipophilic Radical Generators in Hepatic Lysosomal Fractions of Mice. Journal of Health Science. 2000; 46(6): 509-512.

15. Buhler DR and Miranda C. Antioxidant Activities of Flavonoids. (Online) 2000 . http:// Ipi.oregonstate.edu/f-w00/flavonoid.html

16. Siddhuraju P and Becker K. Antioxidant Properities of Various Solvent Extracts of Total Phenolic Constituents from Three Different Agroclimatic Origins of Drumstick Tree (M. oleifera Lam.) Leaves. Journal of Agricultural and Food Chemistry. 2003; 51: 2144-2155.

17. Manguro LO and Lemmen P. Phenolics of Moringa oleifera Leaves. Natural Product Research. 2007; 21(1): 56-68.

18. Lako J, Trenerry VC, Wahlqvist ML, Wattanapenpaiboon N, Subramanium S, and Premier R. 2007. Phytochemical Flavonols, Carotenoids and the Antioxidant Properties of a Wide Selection of Fijian Fruit, Vegetables and Other Readily Available Foods. Food Chemistry. 2007; 101(4): 1727-1741.

19. Middleton E Jr, Kandaswami C, and Theoharides TC. The Effects of Plant Flavonoids on Mammalian Cells: Implications for Inflammation, Heart Disease, and Cancer. Pharmacological Reviews. 2000; 52(4): 673751.

20. Akan Z. Protective Role of Quercetin: Antioxidants
May Protect Cancer Cells from Apoptosis and Enhance Cell Durability. Webmedcentral. 2011; 2(1): 1-11.

21. Sharma V, Joseph C, Ghosh S, Agarwal A, Mishra MK, and Sen E. Kaempferol Induces Apoptosis in Glioblastoma Cells through Oxidative Stress. Molecular Cancer Therapeutics. 2007; 6(9): 25442553.

22. Li W, Du B, Wang T, Wang S, and Zhang J. Kaempferol Induces Apoptosis in Human HCT116 Colon Cancer Cells via the Ataxia-Telangiectasia Mutated-p53 Pathway with the Involvement of p53 Upregulated Modulator of Apoptosis. Chemico-Biological Interactions. 2009; 177(2): 121-127.

23. Luqman Suaib, Srivastava S, Kumar R, Maurya AK, and Chanda D. 2012. Experimental Assessment of Moringa oleifera Leaf and Fruit for Its Antistress, Antioxidant, and Scavenging Potential Using In Vitro and In Vivo Assays. Evidence-Based Complementary and Alternative Medicine. 2011; 2012: 1-12.

24. Humaidah E, Ratnawati R, and Hernowati TE. Pengaruh Ekstrak Metanol Daun Moringa oleifera Terhadap Jumlah Ekspresi Cyclin D1 pada Jaringan Kolon Tikus Wistar yang Diinduksi DMBA. [Skripsi]. Universitas Brawijaya, Malang. 2013.

25. Budda S, Butryee $C$, Tuntipopipat $S$, et al. Suppressive Effects of Moringa oleifera Lam Pod Against Mouse Colon Carcinogenesis Induced by Azoxymethane and Dextran Sodium Sulfate. Asian Pacific Journal of Cancer Preventio. 2011; 12(12): 3221-3228.

16. Sharma V and Paliwal R. Chemo Protective Role of Moringa Oleifera and its Isolated Saponin against DMBA Induced Tissue Damage in Male Mice: A Histopathological Analysis. International Journal of Drug Development and Research. 2012; 4(4): 215-228. 